\title{
THREE-DIMENSIONAL EVALUATION OF IMPACTED MAXILLARY CANINES USING CONE BEAM COMPUTED TOMOGRAPHY AND PANORAMIC RADIOGRAPHS
}

\author{
Sang-Yun Jeon, Nan-Young Lee, Sang-Ho Lee \\ Department of Pediatric Dentistry, College of Dentistry, Chosun University
}

\begin{abstract}
Normal eruption of the canine is important for the transition to the permanent dentition. Etiologies, including premature loss or delayed retention of deciduous teeth, neoplasm and abnormality of lateral incisor can cause impaction of the maxillary canine. Untreated canine impaction can result in malocclusion, cyst formation and obstacles in orthodontic treatment. The aim of this study is to evaluate location of the impacted maxillary canine and to identify correlation between location and management of the impaction including complications. Using panoramic radiographs and CBCT scan, images of 89 children diagnosed with impaction of the maxillary canine, location of impacted canines was evaluated. The choice of treatment and complications were investigated to identify correlation. Results show that the most commonly impacted location of the maxillary canine was in the mid-alveolar area, followed by buccal side and palatal side. Orthodontic traction was selected more frequently than the other treatments. As complications, displacement of adjacent tooth was occurred most frequently. Buccally impacted canines showed increased tendency towards displacement. The more buccally the canine was impacted, the less orthodontic traction was chosen as the treatment. The canine impacted mesially to the central incisor showed increased tendency to occur root resorption. Therefore, early diagnosis by periodic examination, appropriate treatment and intervention is required.
\end{abstract}

Key words : Maxillary cuspid, Impacted tooth, Computed tomography

\section{I. 서 론}

상악 견치는 제3대구치 다음으로 빈번히 매복되는 치아로 전 체 인구의 $1 \sim 2 \%$ 에서 관찰되는데 ${ }^{1)}$, 상악 견치 매복의 유병률 에 대해 Ericson과 $\mathrm{Kurol}^{2)}$ 은 $0.9 \sim 2.0 \%, \mathrm{Fox}$ 등 $^{3)}$ 은 $1.5 \sim 2.0 \%$, 그리고 Stewart 등 $)^{\circ}$ 은 1 3\%로 보고하였다. 여 성에서 남성보다 상악 견치의 매복이 좀 더 빈번하고, 이 중 약 $8 \%$ 는 양측성 매복이 관찰된다 ${ }^{5}$.

상악견치의 매복은 일반적으로 국소적 원인이 많으며 치배의 변위, 치낭과 치주인대의 결함, 유치의 조기 상실 또는 만기 잔 존, 맹출 공간의 부족, 과잉치, 낭종, 치아종, 외상과 이에 따른
유착 등을 주요 원인으로 들 수 있다.

매복 위치에 대해서는 대부분의 연구들에서 구개측에 매복된 경우가 협측에 매복된 경우보다 많다고 보고하였는데 Stellzig 등6)은 매복된 견치의 $85 \%$ 가 구개측에 위치한다고 하였고, Caprioglio 등ㄱㄱㅘ Fournier 등은 국개측 매복과 협측 매복의 비율을 3: 1, Jacoby")는 $12: 1$ 이라고 보고하였다. 그러나 Oliver 등 ${ }^{10}$ 에 따르면 구개측과 협측 매복의 비는 인종에 따라 서 다르다고 하였는데, Caucasian에서는 구개측 매복이 협측 매복보다 2배가 더 많고, Asian에서는 이와 반대로 협측에 매 복된 경우가 더 많다고 하였다. 또한 Liu 등1ㅡ은 매복 견치의 위치를 협측, 구개측, 중앙 치조골 부위의 세 영역으로 나누어

Corresponding author : Nan-Young Lee

Department of Pediatric Dentistry, College of Dentistry, Chosun University, 375 Seosuk-dong, Dong-gu, Gwangju, 501-825, Korea

Tel: +82-62-220-3860 / Fax: +82-62-225-8240 / E-mail: nandent@chosun.ac.kr

Received January 25, 2013 / Revised May 13, 2013 / Accepted May 14, 2013 
서 시행한 연구에서 구개측보다 협측에 더 많이 매복됨을 보고 하였다. 이처럼 아시아인에서는 일반적으로 상악 견치가 치열 궁내 또는 순측에 매복되는 경우가 많으며, 구개측에 매복되는 비율이 유럽인의 $1 / 5$ 로 보고되었다 ${ }^{12)}$.

매복 견치는 인접치의 치근 흡수나 변위, 공간 상실, 부정교 합, 낭종의 발생 등의 합병증을 야기할 수 있으며 이러한 합병 증은 견치의 매복상태가 오래 지속될수록 증가되기 때문에 조 기 진단과 적절한 치료 개입이 필요하다. 매복 견치의 치료방법 으로는 외과적 노출 후 교정적으로 견인하는 방법, 해당 매복 견치를 발거하고 보철적적으로 수복하는 방법, 유견치의 발거, 맹출 공간의 확보, 매복 견치를 발거한 후 재이식하는 방법 등 이 있는데 치료 방법을 결정하기 위해서는 치아의 발육정도, 매 복견치의 협설/근원심적 위치 및 견치 치축의 경사도 등 위치에 대한 정확한 진단이 필요하고, 이와 함께 환자 및 보호자의 협 조 등 많은 요인을 다각적으로 고려해야 한다.

매복된 견치의 위치를 진단하기 위한 자료는 치근단방사선사 진, 교합방사선사진, 파노라마방사선사진이 있다. 이러한 방사 선사진은 2 차원 평면 영상으로 표현되어 피사체가 중첩되거나 왜곡될 수 있는 단점이 있다. 최근에는 매복 견치를 평가하기 위해 치과용 전산화단층촬영 영상(computed tomograph, $\mathrm{CT}$ )을 이용하는데, 이는 매복된 견치의 위치를 3 차원적으로 표 현해 주어 매복 견치의 위치에 대한 보다 정확한 정보를 얻을 수 있다.

현재까지 매복된 상악 견치의 3차원적 위치에 대한 연구들이 많이 보고되었다. 이러한 연구들은 대개 인접치아 또는 상악골 의 기준점을 이용하여 이에 대한 견치의 위치정보를 기술하였 거나, 또는 이러한 위치 정보와 견치의 맹출 가능성에 대한 연 구들이었으며, 매복된 견치의 3 차원적 위치관계와 치료법 및 합병증에 대한 상관관계를 보고한 연구는 많지 않다.

이 연구의 목적은 Cone-beam CT (CBCT) 영상과 파노라 마방사선영상을 이용하여 매복된 상악 견치의 위치를 조사하 고, 위치관계와 치료 및 발생된 합병증과의 관계를 알아보기 위 한 것이다.

\section{II . 연구 재료 및 방법}

\section{1. 연구대상}

2006년부터 2012년까지 조선대학교치과병원 소아치과에서 매복된 상악 견치의 검사를 위해 파노라마방사선 촬영과 CBCT (CB Mercury, Hitachi, Tokyo, Japan) 촬영을 시행 한 환자 중 구개열 또는 전신질환 등으로 인해 상악골의 전반적 인 발육부전을 나타내는 경우와 다수의 매복치를 보이는 증례 를 제외한 89명의 환자를 대상으로 하였다.

총 89 명의 환자의 평균 나이는 11.15 세(8 18세)이며, 이 중 남자는 37 명, 여자는 52 명이었다. 양측성 견치 매복을 보이 는 경우를 포함하여 총 매복 상악 견치의 수는 106 개였다.

\section{2. 연구방법}

파노라마방사선영상과 $\mathrm{CBCT}$ 로 촬영한 후 재구성한 축면 영 상, 시상면 영상, 관상면 영상, 그리고 3차원 입체영상 자료를 영상 프로그램( $\pi$-ViewStar, Infinitt Co., Seoul, Korea)을 이 용하여 매복된 상악 견치를 평가하였다. 매복된 견치의 교두정 을 기준으로 협-구개(bucco-palatal) 위치 관계, 근-원심 (mesio-distal) 위치 관계, 수직적 위치(vertical position) 관 계, 견치 장축이 이루는 각도, 치료, 합병증 그리고 원인에 대해 조사하였다. 촬영 영상의 검사와 분석은 한 명의 검사자에 의해 시행되었다.

1) 횡단면에서 견치의 협-구개 위치

횡단면에서 매복된 상악 견치의 위치를 3 가지 영역으로 나누 어 분류하였다(Fig. 1). 협측은 치열궁 협측에 견치 교두정이 위치하는 경우, 치열궁내(within the arch)는 치열궁내에 견치 의 교두정이 위치하는 경우, 그리고 구개측은 치열궁의 구개측 에 매복된 견치 교두정이 위치하는 경우로 정의하였다.

\section{2) 근-원심 위치}

매복된 견치의 근원심적 위치관계를 조사하기 위해 중절치, 측절치, 제 1 소구치 치축을 기준으로 하여 중절치 치축의 근심 영역을 중절치 영역(central incisor area), 중절치 치축과 측 절치 치축 사이의 영역을 측절치 영역(lateral incisor area), 측절치 치축과 제 1 소구치 치축 사이 영역을 견치 영역 (canine area), 그리고 제 1 소구치 치축의 원심 영역을 소구치 영역 (premolar are)으로 구분하였다(Fig. 2). 매복된 견치의 교두 정이 위의 4 가지 영역 중 어느 영역에 위치하는지 파노라마방 사선 영상에서 분석하였다.

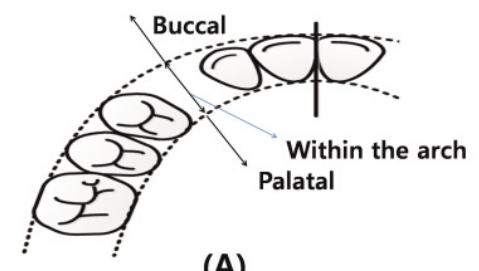

(A)

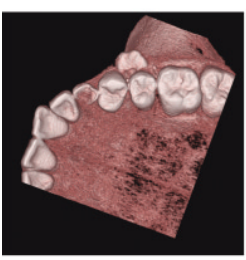

(B)

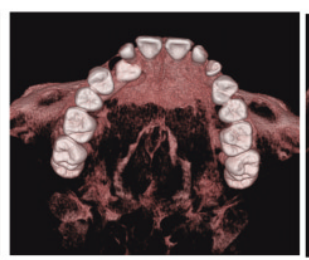

(C)

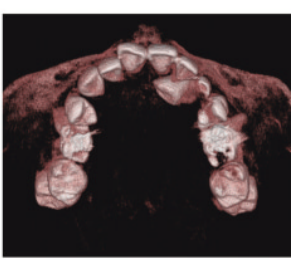

(D)
Fig. 1. The bucco-palatal position of cuspal tip of impacted canine in transverse plane. (A) Buccal area represents the area buccal side to dental arch, the area within the arch represents the area within the dental arch, and the palatal area represents the area palatal side to dental arch. (B) (D) The 3D images of impacted maxillary canines located at buccal area (B), within the $\operatorname{arch}(\mathrm{C})$, and palatal area (D). 


\section{3) 수직적 위치관계}

인접한 측절치 치근을 수직적으로 치경부(near cervical), 치 근부(near apical), 치근단 상부(beyond apical)의 세 영역으 로 구분한 뒤 $\mathrm{CBCT}$ 영상과 파노라마방사선영상에서 견치 교두 정이 어느 영역에 위치하는지 조사하였다(Fig. 3).

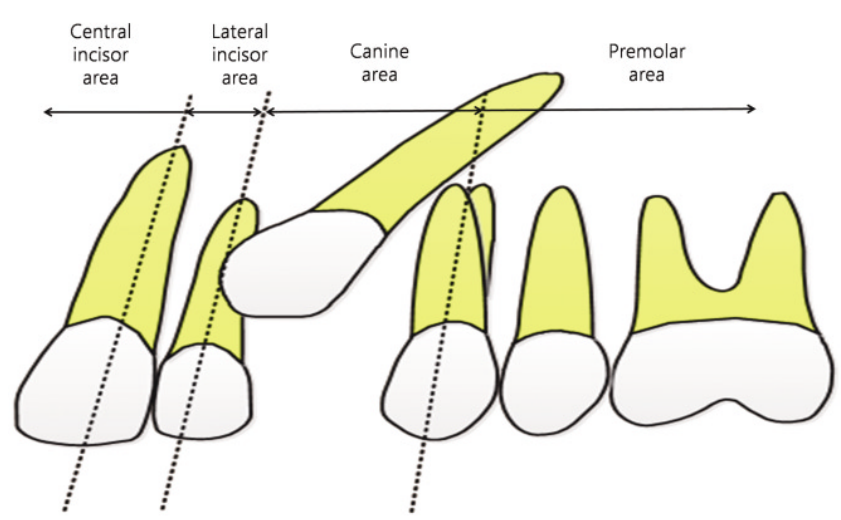

(A)

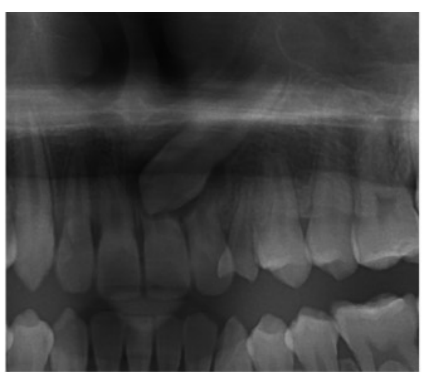

(B)

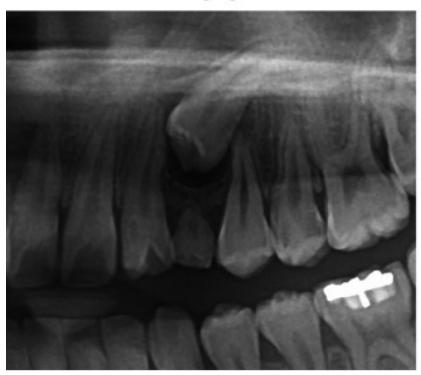

(D)

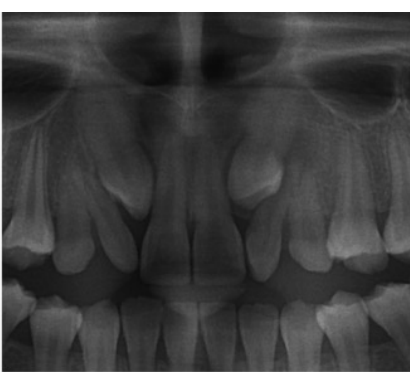

(C)

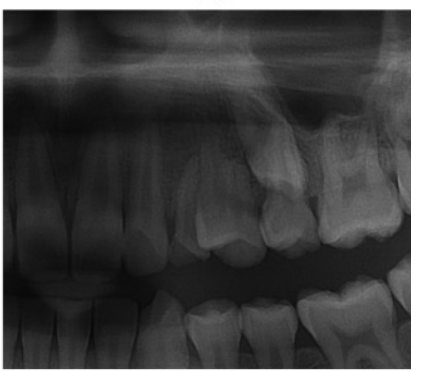

(E)
Fig. 2. The mesio-distal position of cuspal tip of impacted canine in panoramic radiographs. (A) Central incisor area corresponds to the area mesial to the long axis of central incisor, the lateral incisor area indicates the area between the long axes of central incisor and lateral incisor, the canine area indicates the area between the long axes of the lateral incisor and the first premolar, and the premolar area indicates the area distal to the long axis of first premolar. (B) (E) Panoramic radiographs of impacted maxillary canines located at central incisor area (B), lateral incisor area (C), canine area (D), and premolar area (E).

\section{4) 교합평면으로부터의 거리}

상악 중절치 절단연과 상악 제 1 대구치 근심협측교두를 연결 한 평면을 교합평면으로 설정하고 이 평면과 견치 교두정 사이 의 수직 거리를 파노라마방사선영상에서 측정하였다(Fig. 4).

5) 교합평면과 견치 장축이 이루는 각

설정된 교합평면과 매복된 견치의 장축이 이루는 각을 측정 하였다(Fig. 5).

6) 양측 과두 최상부점을 연결한 선과 견치 장축이 이루는 각 Waford 등히이 제안한 바와 같이 양측 과두 최상부점을 연결 한 bicondylar line과 견치 장축이 이루는 각을 측정하였다 (Fig. 6).

7) 매복된 견치에 의해 발생한 합병증

매복된 상악 견치에 의해 발생한 합병증을 인접 치근의 흡수, 인접 치아의 변위(displacement), 인접 치아의 매복, 낭종의 형성의 범주로 나누어 조사하였다.

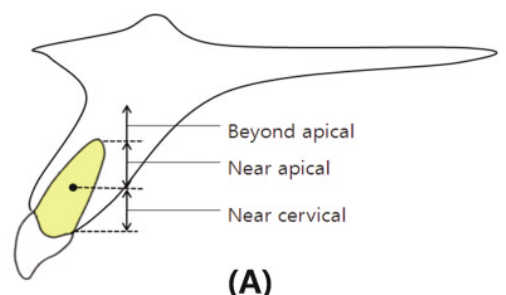

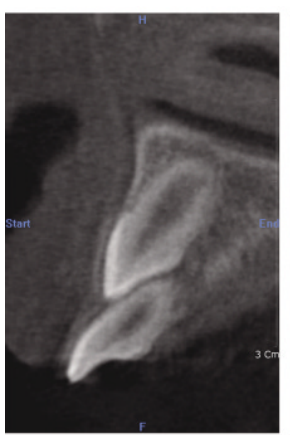

(B)

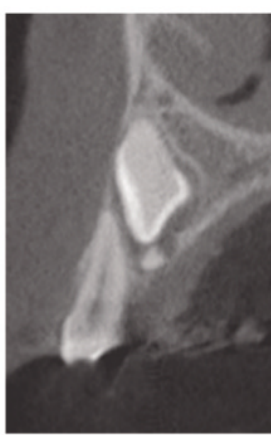

(C)

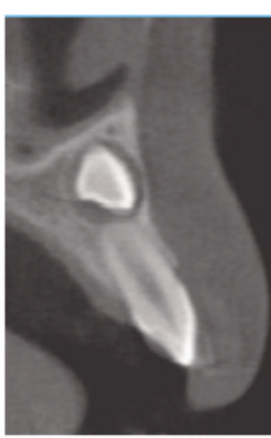

(D)
Fig. 3. The vertical position of cuspal tip of an impacted canine in the sagittal plane. (A) Area near cervix (near cervical) indicates the area between the crest of alveolar bone and middle of the lateral incisor root, the area near apex (near apical) indicates the area between the middle of root and the root apex, the area beyond apex (beyond apical) indicates the area upper to root apex. (B) (D) Sagittal view of impacted canine located near cervical (B), near apical (C), and beyond apical (D). 


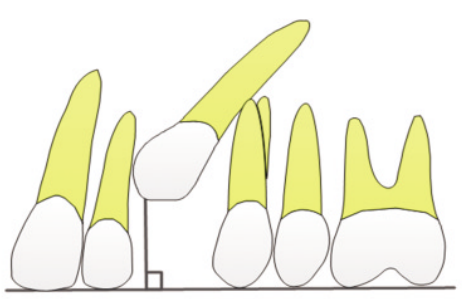

(A)

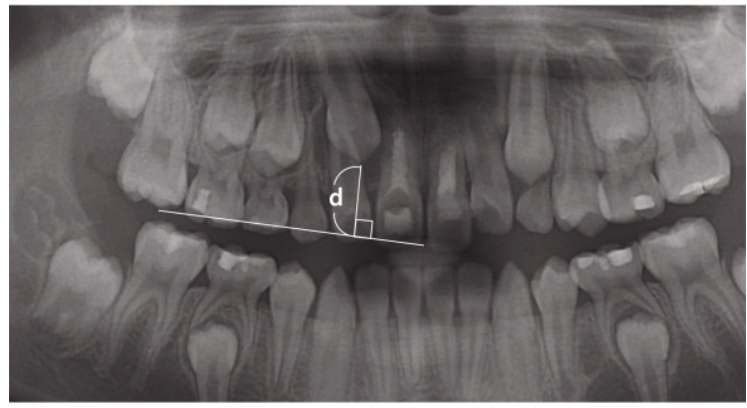

(B)

Fig. 4. Distance (d) from the tip of the impacted canine to the occlusal plane. Occlusal plane is defined as the plane which connects the mesiobuccal cusp of the maxillary first molar and the mid-point of the incisal edge of the bilateral maxillary central incisor.

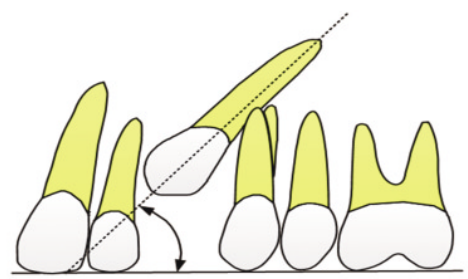

(A)

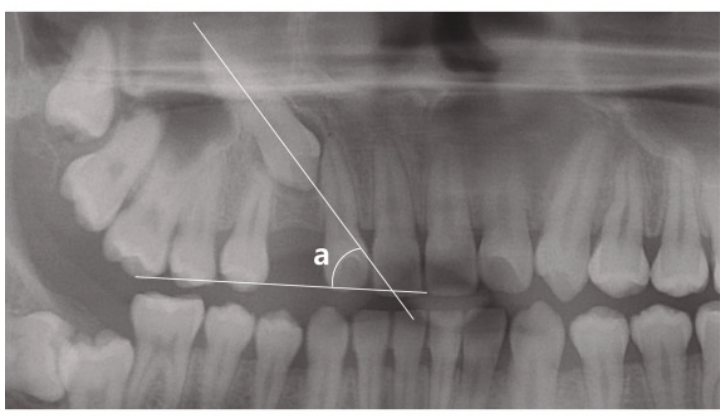

(B)

Fig. 5. Angulation of the impacted canine to the occlusal plane (a)

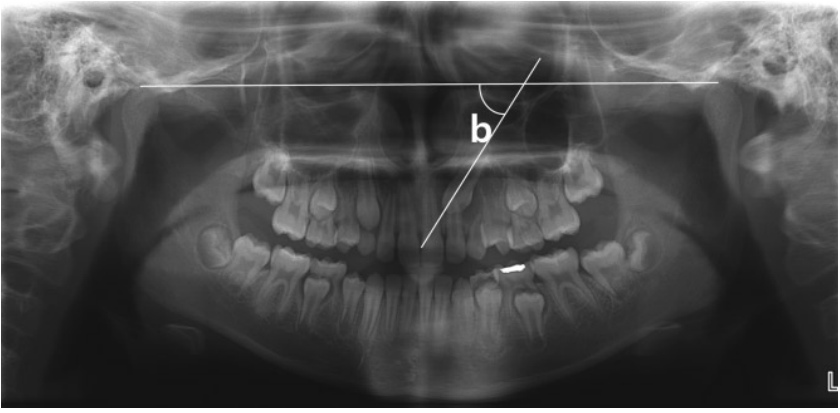

Fig 6. Angulation of the impacted canine to the bicondylar line (b). Bicondylar line is defined as the line which connect the right and left most superior point of condyle.

\section{8) 추정되는 원인}

견치의 매복을 야기했다고 추정되는 원인을 신생물(예, 치아 종), 낭종, 상악 측절치의 이상(peg-shaped tooth, missing 등), 매복된 견치의 발육이상, 맹출 공간의 부족, 특발성 매복 (특이 국소 원인 요소가 관찰되지 않는 경우)의 범주로 나누어 조사하였다.

\section{9) 치료}

매복된 견치에 시행된 치료를 교정적 견인, 매복된 해당 견치 의 발거, 유견치의 발거, 다른 영구치의 발거, 치아종 같은 신생 물이나 낭종의 제거, 이식, 맹출 공간의 확보, 관찰의 범주로 나 누어 조사하였다. 단순히 유견치의 발거나 낭종의 제거 등을 시 행한 경우 해당 범주로 포함시켰고 이러한 치료 이후에 결국에 교정적 견인을 시행한 경우 교정적 견인 범주에 포함시켰다.

\section{0) 통계적인 분석}

파노라마방사선영상과 $\mathrm{CBCT}$ 영상으로부터 측정된 자료는 SPSS 20 (SPSS Inc., Chicago, IL, USA)을 이용하여 $\boldsymbol{x}^{2}-$ test, Fisher's exact test, Logistic regression test $(\alpha=$ $0.05)$ 를 이용하여 통계적으로 분석하였다.

\section{III. 연구 성적}

\section{1. 성별, 좌우 분포}

총 89명을 대상으로 하였으며, 이중 남자가 32 명, 여자가 57 명이었다. 매복된 견치의 총 개수는 106 개였으며, 이중 우측 견 치가 47 개 (44.3\%), 좌측 견치가 59개 (55.7\%)였다.

\section{2. 협-구개 위치}

횡단면에서의 협-구개 위치는 견치 교두정을 기준으로 치열 궁내에 위치하는 경우가 58 개(54.7\%)로 가장 많았으며, 그 다 
음으로 치열궁의 협측에 30 개(28.3\%), 구개측에 18 개 (17.0\%)의 분포를 보였다(Table 1).

\section{3. 근-원심 위치}

측절치 치축 근심의 측절치 영역에 51 개 $(48.1 \%)$ 로 가장 많 은 매복 견치가 위치했으며, 그 다음으로 견치 영역 35 개 $(33.0 \%)$, 소구치 영역 11 개(10.4\%), 중절치 영역 9개 $(8.5 \%)$ 순서로 나타났다(Table 2).

\section{4. 수직적 위치}

매복된 견치는 인접한 측절치를 기준으로 치근부에 존재하는 경우가 50개(47.2\%)로 가장 많았고, 치경부 42개(39.6\%), 치근단 상부 14 개(13.2\%)의 분포를 보였다(Table 3).

\section{5. 견치 장축이 이루는 각과 교합평면으로부터의 거리}

1) 교합평면으로부터 거리

설정된 교합평면에서 견치 교두정까지 수직 거리는 평균 $15.1 \pm 4.5 \mathrm{~mm}$ 로 조사되었다(Table 4).

Table 1. Bucco-palatal location of impacted maxillary canines in transverse plane

\begin{tabular}{lcc}
\hline \multicolumn{1}{c}{ Sector } & Number & $\%$ \\
\hline Buccal & 30 & 28.3 \\
Within the arch & 58 & 54.7 \\
Palatal & 18 & 17.0 \\
\hline Total & 106 & 100.0 \\
\hline
\end{tabular}

Table 2. Mesio-distal location of impacted maxillary canines in panoramic view

\begin{tabular}{lcc}
\hline \multicolumn{1}{c}{ Sector } & Number & $\%$ \\
\hline Central incisor area & 9 & 8.5 \\
Lateral incisor area & 51 & 48.1 \\
Canine area & 35 & 33.0 \\
Premolar area & 11 & 10.4 \\
\hline Total & 106 & 100.0 \\
\hline
\end{tabular}

Table 3. Vertical location of impacted maxillary canines in sagittal plane

\begin{tabular}{lcc}
\hline \multicolumn{1}{c}{ Sector } & Number & $\%$ \\
\hline Near cerical & 42 & 39.6 \\
Near apical & 50 & 47.2 \\
Beyond apical & 14 & 13.2 \\
\hline Total & 106 & 100.0 \\
\hline
\end{tabular}

\section{2) 견치 장축이 이루는 각}

(1) 교합평면과 이루는 각

교합평면과 이루는 각은 평균 $56.0 \pm 25.4^{\circ}$ 이었다(Table 4).

(2) 양측 과두 최상부점을 연결한 선과 이루는 각

양측 과두 연결선과 이루는 각은 평균 $64.6 \pm 28.5^{\circ}$ 이었다 (Table 4).

6. 치료

교정적 견인이 가장 많이 시행되었고(41개, $38.7 \%$ ), 그 다음 으로는 해당 견치의 발거, 특별한 치료 없이 관찰, 유견치의 발 거, 맹출 경로상의 낭종이나 신생물의 제거, 다른 영구치의 발 거, 치아이식, 맹출 공간의 확보 순서로 나타났다(Table 5). 치 료를 계획하였으나 내원하지 않은 경우는 기타로 범주화하였다.

\section{7. 매복된 견치의 위치/경사도와 치료와의 상관관계}

매복된 견치의 위치관계와 치료 중 교정적 견인과의 상관관 계를 검사한 결과 매복된 견치의 협-구개, 근심-원심 위치와 교 합평면으로부터의 거리, 교합평면과 이루는 각도는 교정적 견 인의 선택에 영향을 미쳤으며 $(p<0.05)$, 견치의 수직적 위치 와는 통계적인 관련성이 없었다 $(p>0.05)$ (Table 6).

Logistic regression test를 이용해 위의 변수들과의 상관관 계의 정도를 보면, 매복된 견치가 치열궁 내에 위치했을 경우에 비해 협측에 위치할 경우 교정적 견인이 시행되는 odds ratio가 0.126 으로 현저히 적었다. 근원심적 위치관계에서 견치 영역과 비교할 때, 교정적 견인에 대해 통계적으로 유의한 odds ratio

Table 4. Distance from occlusal plane and angulation of canine to the reference planes

\begin{tabular}{lccc}
\hline & Distance from & \multicolumn{2}{c}{ Angulation (degree) } \\
\cline { 3 - 4 } & OP $(\mathrm{mm})$ & Occlusal plane & Bicondylar line \\
\hline Mean & 15.1 & 56.0 & 64.6 \\
S.D. & 4.5 & 25.4 & 28.5 \\
\hline
\end{tabular}

Table 5. Treatment for impacted maxillary canines

\begin{tabular}{lcr}
\hline \multicolumn{1}{c}{ Treatment } & Number of canines & $\%$ \\
\hline Orthodontic traction & 41 & 38.7 \\
Extraction of impacted canine & 24 & 22.6 \\
Extraction of primary tooth & 6 & 5.7 \\
Extraction of other permanent tooth & 4 & 3.8 \\
Removal of cyst/neoplasm & 5 & 4.7 \\
Autotransplantation & 3 & 2.8 \\
Space regaining & 1 & 0.9 \\
Only Observation without treatment & 7 & 6.6 \\
Etc. & 15 & 14.2 \\
\hline Total & 106 & 100.0 \\
\hline
\end{tabular}


Table 6. Correlation between location/angulation of impacted canine and orthodontic traction

\begin{tabular}{|c|c|c|c|c|c|}
\hline \multirow{2}{*}{ Location/Angulation } & \multirow{2}{*}{ Classification } & \multicolumn{3}{|c|}{ Treatment } & \multirow{2}{*}{$p$-value } \\
\hline & & Orthodontic traction & etc. & Total & \\
\hline \multirow{3}{*}{ Bucco-palatal position } & Buccal & 4 & 26 & 30 & \multirow{3}{*}{$0.014 *$} \\
\hline & Within the arch & 29 & 29 & 58 & \\
\hline & Palatal & 8 & 10 & 18 & \\
\hline \multirow{4}{*}{ Mesio-distal position } & Central incisor area & 1 & 8 & 9 & \multirow{4}{*}{$0.001^{*}$} \\
\hline & Lateral incisor area & 29 & 22 & 51 & \\
\hline & Canine area & 10 & 25 & 35 & \\
\hline & Premolar area & 1 & 10 & 11 & \\
\hline \multirow{3}{*}{ Vertical position } & Near cervical & 17 & 25 & 42 & \multirow{3}{*}{0.646} \\
\hline & Near apical & 19 & 31 & 50 & \\
\hline & Beyond apical & 5 & 9 & 14 & \\
\hline Distance & Distance from occlusal plane & & & & $0.014^{*}$ \\
\hline \multirow{2}{*}{ Angulation } & Angulation to occlusal plane & & & & $0.037^{*}$ \\
\hline & Angulation to bicondylar line & & & & 0.331 \\
\hline
\end{tabular}

Chi-square test, Fisher's Exact test

$*$ : statistical significance $(p<0.05)$

Table 7. Degree of correlation between location/angulation and treatment

\begin{tabular}{|c|c|c|c|c|c|c|}
\hline \multirow{2}{*}{\multicolumn{2}{|c|}{ Position of canines }} & \multirow{2}{*}{ B } & \multirow{2}{*}{ Significance } & \multirow{2}{*}{ Odds ratio } & \multicolumn{2}{|c|}{ 95\% C.I. } \\
\hline & & & & & lower & upper \\
\hline \multirow{3}{*}{ B-P position } & Within the arch & Reference & $0.013^{*}$ & & & \\
\hline & Buccal & -2.072 & $0.003^{*}$ & 0.126 & 0.031 & 0.506 \\
\hline & Palatal & -0.795 & 0.277 & 0.452 & 0.108 & 1.890 \\
\hline \multirow{4}{*}{ M-D position } & Canine area & Reference & $0.025^{*}$ & & & \\
\hline & Lateral incisor area & -0.787 & 0.170 & 0.455 & 0.148 & 1.40 \\
\hline & Central incisor area & 1.287 & 0.187 & 3.621 & 0.535 & 24.512 \\
\hline & Premolar area & -2.452 & 0.066 & 0.086 & 0.006 & 1.178 \\
\hline \multirow{3}{*}{ Vertical position } & Near apical & Reference & 0.370 & & & \\
\hline & Near cervical & 0.827 & 0.350 & 2.286 & 0.404 & 12.926 \\
\hline & Beyond apical & 0.844 & 0.459 & 2.326 & 0.250 & 21.678 \\
\hline \multicolumn{2}{|c|}{ Distance from occlusal plane } & -0.204 & $0.014 *$ & 0.816 & 0.693 & 0.960 \\
\hline \multicolumn{2}{|c|}{ Angulation to occlusal plane } & -0.046 & $0.037^{*}$ & 0.955 & 0.915 & 0.997 \\
\hline \multicolumn{2}{|c|}{ Angulation to bicondylar line } & 0.059 & 0.229 & 1.061 & 0.964 & 1.168 \\
\hline
\end{tabular}

Logistic regression test

$*$ : statistical significance $(p<0.05)$

C.I. : Confidence interval

를 나타내는 변수는 없었다. 교합평면으로부터의 거리가 증가 할수록, 교합평면과 이루는 각이 커질수록 매복된 견치의 교정 적 견인에 대한 odds ratio는 각각 $0.816,0.966$ 로 나타났다 (Table 7).

\section{8. 합병증}

합병증이 관찰된 경우가 72 개로 전체의 $87.4 \%$ 를 차지했으 며 이중에서도 인접치근을 변위시키는 합병증이 59개로 전체 합병증의 $72.0 \%$, 전체 표본의 $55.7 \%$ 를 차지하였다. 그 다음 으로는 합병증이 관찰되지 않는 경우가 24 개( $22.6 \%$ ), 인접 치 근의 흡수가 16 개(15.1\%), 낭종 형성 6개(5.7\%), 인접 치아 의 매복이 1 개(0.9\%)로 나타났다(Table 8).
Table 8. Complications of impacted maxillary canines

\begin{tabular}{lcr}
\hline \multicolumn{1}{c}{ Complications } & Number of canines & $\%$ \\
\hline Resorption of adjacent root & 16 & 15.1 \\
Impaction of adjacent tooth & 1 & 0.9 \\
Displacement of adjacent tooth & 59 & 55.7 \\
Cyst formation & 6 & 5.7 \\
No complication & 24 & 22.6 \\
\hline Total & 106 & 100.0 \\
\hline
\end{tabular}

9. 매복된 견치의 위치/경사도와 합병증과의 상관관계

조사한 합병증 중 가장 많이 관찰되었던 인접치근의 흡수와 인 접치아의 변위와 견치의 위치관계와의 상관관계를 조사하였다. 
Table 9. Correlation between location/angulation of impacted canine and root resorption

\begin{tabular}{|c|c|c|c|c|c|}
\hline \multirow{2}{*}{ Location/Angulation } & \multirow{2}{*}{ Classification } & \multicolumn{3}{|c|}{ Complication } & \multirow{2}{*}{$p$-value } \\
\hline & & Resorption & etc. & Total & \\
\hline \multirow{3}{*}{ Bucco-palatal position } & Buccal & 2 & 28 & 30 & \multirow{3}{*}{0.106} \\
\hline & Within the arch & 13 & 45 & 58 & \\
\hline & Palatal & 1 & 17 & 18 & \\
\hline \multirow{4}{*}{ Mesio-distal position } & Central incisor area & 5 & 4 & 9 & \multirow{4}{*}{$0.007 *$} \\
\hline & Lateral incisor area & 8 & 43 & 51 & \\
\hline & Canine area & 2 & 33 & 35 & \\
\hline & Premolar area & 1 & 10 & 11 & \\
\hline \multirow{3}{*}{ Vertical position } & Near cervical & 7 & 35 & 42 & \multirow{3}{*}{0.669} \\
\hline & Near apical & 8 & 42 & 50 & \\
\hline & Beyond apical & 1 & 13 & 14 & \\
\hline Distance & Distance from occlusal plane & & & & 0.294 \\
\hline \multirow{2}{*}{ Angulation } & Angulation to occlusal plane & & & & 0.416 \\
\hline & Angulation to bicondylar line & & & & 0.308 \\
\hline
\end{tabular}

Chi-square test, Fisher's Exact test

$*$ : statistical significance $(p<0.05)$

Table 10. Correlation between location/angulation of impacted canine and displacement

\begin{tabular}{|c|c|c|c|c|c|}
\hline \multirow{2}{*}{ Location/Angulation } & \multirow{2}{*}{ Classification } & \multicolumn{3}{|c|}{ Complication } & \multirow{2}{*}{$p$-value } \\
\hline & & Displacement & etc. & Total & \\
\hline \multirow{3}{*}{ Bucco-palatal position } & Buccal & 21 & 9 & 30 & \multirow{3}{*}{0.080} \\
\hline & Within the arch & 26 & 32 & 58 & \\
\hline & Palatal & 12 & 6 & 18 & \\
\hline \multirow{4}{*}{ Mesio-distal position } & Central incisor area & 4 & 5 & 9 & \multirow{4}{*}{0.268} \\
\hline & Lateral incisor area & 33 & 18 & 51 & \\
\hline & Canine area & 17 & 18 & 35 & \\
\hline & Premolar area & 5 & 6 & 11 & \\
\hline \multirow{3}{*}{ Vertical position } & Near cervical & 31 & 11 & 42 & \multirow{3}{*}{$<0.0001^{*}$} \\
\hline & Near apical & 26 & 24 & 50 & \\
\hline & Beyond apical & 2 & 12 & 14 & \\
\hline Distance & Distance from occlusal plane & & & & 0.307 \\
\hline \multirow{2}{*}{ Angulation } & Angulation to occlusal plane & & & & 0.312 \\
\hline & Angulation to bicondylar line & & & & 0.087 \\
\hline
\end{tabular}

Chi-square test, Fisher's Exact test

$*$ : statistical significance $(p<0.05)$

견치의 근심-원심 위치만이 인접 치근흡수의 발생과 상관관 계가 있는 것으로 나타났으며 $(p<0.05)$, 그 외의 변수들은 관 련성을 보이지 않았다 $(p>0.05)$. 견치의 수직적 위치가 인접 치아의 변위와 상관관계가 있는 것으로 조사되었다 $(p<0.05)$ (Table 9, 10).

인접 치근 흡수와 견치의 위치관계에 따른 관련성을 분석한 logistic regression test 분석 결과를 보면, 견치가 견치 영역 에 위치했을 경우와 비교하여 중절치 근심 영역에 위치할 경우 인접 치근의 흡수에 대한 odds ratio가 37.703으로 매우 높게 나타났다. 교합평면으로부터의 거리와 교합평면과 견치 장축이 이루는 각, 그리고 양측 과두 상부점을 연결한 선과 견치 장축 이 이루는 각은 인접 치근의 흡수와는 통계적으로 유의한 관련 성이 나타나지 않았다(Table 11).
매복된 견치의 위치관계에 따른 인접 치아를 변위시키는 경 향을 살펴보면, 견치가 치열궁에 위치할 경우와 비교하여 협측 에 위치할 경우 인접 치아 변위에 대한 odds ratio가 5.771로 나타났고, 근원심적 위치관계에서 견치영역에 위치할 경우와 비교하여 측절치 근심에 존재할 경우 인접 치아 변위에 대한 odds ratio는 4.133으로 나타났다. 또한 견치가 인접 측절치 치근단 부근에 위치할 경우에 비교하여 치근단 상부에 존재할 경우 인접 치아 변위에 대한 odds ratio는 0.028로 나타났다. 인접 치근 흡수경향과 마찬가지로 인접 치아를 변위시키는 경 향도 교합평면으로부터의 거리, 교합평면과 이루는 각, 양측 과 두 상부점을 연결한 선과 이루는 각과는 유의적인 관련성이 발 견되지 않았다(Table 12). 
Table 11. Degree of correlation between location/angulation of impacted canine and resorption

\begin{tabular}{|c|c|c|c|c|c|c|}
\hline \multirow{2}{*}{\multicolumn{2}{|c|}{ Position of canines }} & \multirow{2}{*}{ B } & \multirow{2}{*}{ Significance } & \multirow{2}{*}{ Odds ratio } & \multicolumn{2}{|c|}{ 95\% C.I. } \\
\hline & & & & & lower & upper \\
\hline \multirow{3}{*}{ B-P position } & Within the arch & Reference & 0.069 & & & \\
\hline & Buccal & -1.315 & 0.153 & 0.286 & 0.614 & 22.604 \\
\hline & Palatal & -2.457 & 0.047 & 0.086 & 0.019 & 5.444 \\
\hline \multirow{4}{*}{ M-D position } & Canine area & Reference & $0.014 *$ & & & \\
\hline & Lateral incisor area & 1.230 & 0.142 & 3.420 & 0.663 & 17.647 \\
\hline & Central incisor area & 3.630 & $0.001^{*}$ & 37.703 & 4.083 & 348.199 \\
\hline & Premolar area & 1.070 & 0.436 & 2.915 & 0.198 & 42.920 \\
\hline \multirow{3}{*}{ Vertical position } & Near apical & Reference & 0.619 & & & \\
\hline & Near cervical & -0.548 & 0.554 & 0.578 & 0.282 & 10.632 \\
\hline & Beyond apical & -1.022 & 0.486 & 0.360 & 0.017 & 22.726 \\
\hline \multicolumn{2}{|c|}{ Distance from occlusal plane } & -0.121 & 0.294 & 0.886 & 0.707 & 1.111 \\
\hline \multicolumn{2}{|c|}{ Angulation to occlusal plane } & 0.057 & 0.416 & 1.059 & 0.922 & 1.216 \\
\hline \multicolumn{2}{|c|}{ Angulation to bicondylar line } & -0.019 & 0.308 & 0.982 & 0.947 & 1.017 \\
\hline
\end{tabular}

Logistic regression test

C.I. : Confidence interval

$*$ : statistical significance $(p<0.05)$

Table 12. Degree of correlation between location/angulation of impacted canine and displacement

\begin{tabular}{|c|c|c|c|c|c|c|}
\hline \multirow{2}{*}{\multicolumn{2}{|c|}{ Position of canines }} & \multirow{2}{*}{$\mathrm{B}$} & \multirow{2}{*}{ Significance } & \multirow{2}{*}{ Odds ratio } & \multicolumn{2}{|c|}{ 95\% C.I. } \\
\hline & & & & & lower & upper \\
\hline \multirow{3}{*}{ B-P position } & Within the arch & Reference & $0.022 *$ & & & \\
\hline & Buccal & 1.753 & $0.012^{*}$ & 5.771 & 1.462 & 22.785 \\
\hline & Palatal & 1.315 & 0.100 & 3.726 & 0.778 & 17.853 \\
\hline \multirow{4}{*}{ M-D position } & Canine area & Reference & $0.012^{*}$ & & & \\
\hline & Lateral incisor area & 1.419 & $0.018^{*}$ & 4.133 & 1.28 & 13.344 \\
\hline & Central incisor area & -0.245 & 0.797 & 0.783 & 0.121 & 5.054 \\
\hline & Premolar area & -1.991 & 0.064 & 0.137 & 0.017 & 1.120 \\
\hline \multirow{3}{*}{ Vertical position } & Near apical & Reference & $0.002 *$ & & & \\
\hline & Near cervical & 0.748 & 0.161 & 2.114 & 0.742 & 6.018 \\
\hline & Beyond apical & -3.568 & $0.004^{*}$ & 0.028 & 0.002 & 0.322 \\
\hline \multicolumn{2}{|c|}{ Distance from occlusal plane } & -0.102 & 0.307 & 0.903 & 0.743 & 1.098 \\
\hline \multicolumn{2}{|c|}{ Angulation to occlusal plane } & -0.042 & 0.312 & 0.959 & 0.984 & 1.143 \\
\hline \multicolumn{2}{|c|}{ Angulation to bicondylar line } & 0.059 & 0.124 & 1.060 & 0.997 & 1.049 \\
\hline
\end{tabular}

Logistic regression test

C.I. : Confidence interval

* : statistical significance $(p<0.05)$

\section{0. 원인}

매복을 야기했을 것으로 추정되는 국소적인 요인이 관찰되지 않은 경우가 60개(56.6\%)로 가장 많았고, 그 다음으로 상악 측절치의 발육 이상이 20 개(18.9\%)로 그 뒤를 이었으며, 맹출 공간의 부족 8 개 $(7.5 \%)$, 치아종 8 개 $(7.5 \%)$, 낭종 6 개 $(5.7 \%)$, 기타 4개 (3.8\%) 순으로 나타났다(Table 13).

\section{IV. 총괄 및 고찰}

본 연구에서 매복된 상악 견치는 이전의 연구 결괃ㅇㅇㅘ 유사하 게 우측보다 좌측에서 더 많았고, 남성보다 여성에서 더 많이 관찰되었다. Caucasian을 대상으로 한 대부분의 연구들이 구
Table 13. Causes of impacted maxillary canines

\begin{tabular}{lcr}
\hline \multicolumn{1}{c}{ Causes } & Number of canines & $\%$ \\
\hline Unexplained & 60 & 56.6 \\
Odontoma & 8 & 7.5 \\
Cyst & 6 & 5.7 \\
Abnormality of lateral incisor & 20 & 18.9 \\
Abnormality of impacted canine & 0 & 0.0 \\
Deficiency of eruption space & 8 & 7.5 \\
Etc. & 4 & 3.8 \\
\hline Total & 106 & 100.0 \\
\hline
\end{tabular}

개측에 매복된 견치가 협측 매복보다 많다고 보고하였고 협-구 개측 위치관계를 세 영역으로 구분하여 조사한 연구에서도 대 부분이 구개측에 위치한다고 보고하였지만 ${ }^{6-9.14)}$, Asian을 대상 
으로 한 Liu 등1의 연구에서는 협측 매복이 더 많음을 보고한 바 있다. 한국인을 대상으로 시행된 최근의 Jung 등하에 의한 연구에서는 순측, 치열궁내, 그리고 구개측의 순서를 보였다. 본 연구에서는 치열궁내에 가장 많이 존재하고 그 다음으로 협 측에서 구개측보다 더 높은 빈도로 매복이 관찰되었다. 성별분 포와 좌우 견치의 유병률은 연구 대상이 된 표본이 무작위 추출 된 표본이 아니었기 때문에 통계적인 분석은 시행하지 않았다.

Warford 등13)은 견치 교두정의 근원심적 위치가 매복을 예측 하는데 있어 가장 중요한 요소라고 하였다. 본 연구에서 근원심 적 위치 중 가장 많이 분포된 것으로 조사된 lateral incisor area는 Warford 등하의 연구에서 sector III와 IV에 해당하는 데, 이 경우 견치 장축의 경사도에 따라 75 99\%의 확률로 매 복된다고 보고하였고, 이를 토대로 견치 교두정이 측절치 장축 의 근심에 위치할 경우 견치 매복을 조기에 예상할 수 있다고 생각된다.

이와 달리 Sajnani와 King ${ }^{16}$ 은 교합평면으로부터 교두정까 지의 거리가 매복을 예측하는데 있어 가장 중요한 요소라고 하 였다. 본 연구의 연구대상의 연령 범위는 8세에서 18 세였는데, Sajnani와 King의 연구에서 8 18세 환아들의 각 연령별 교합 평면으로부터 견치 교두정까지의 평균 거리는 $15.7 \sim 20.2 \mathrm{~mm}$ 이었고, 본 연구에서는 평균 $15.1 \mathrm{~mm}$ 의 결과를 보였다. 본 연 구에서는 파노라마방사선사진에서 교합평면으로부터 교두정까 지 거리를 측정하였다. 파노라마방사선사진은 실상보다 확대되 어 나타나고 치열궁의 형태, 조사각도 등에 의해 왜곡될 수 있 으나 본 연구에서는 이에 대한 보정은 시행하지 않았기 때문에 얻어진 수치가 실제 교합평면부터의 거리와는 차이가 있을 수 있을 것으로 생각한다. 일반적인 견치의 경우, 인접치 치근에 대한 수직적 위치관계와 교합평면으로부터의 거리 등이 견치의 맹출 정도에 따라 지속적으로 변화할 것이나, 본 연구에서는 매 복된 견치를 전제로 하였기 때문에 치근 성장 및 맹출에 따른 위치 변화에 대한 보정을 시행하지 않았다.

Kim 등ㄱ은 평균 연령 10.9 세인 25 명의 매복된 상악 견치 35 개를 조사하였는데, 견치 장축과 교합평면이 이루는 각이 파 노라마방사선사진 상에서 $48.70 \pm 19.26^{\circ}, \mathrm{CBCT}$ 영상에서 $53.53 \pm 16.32^{\circ}$ 라고 보고하였고, $\mathrm{CBCT}$ 영상에서보다 파노 라마방사선사진 상에서 더 작게 측정된다고 하였다. 따라서 본 연구에서는 파노라마방사선사진 상에서 측정하였는데 평균 $56.0 \pm 25.4^{\circ}$ 의 결과를 보였으나 $\mathrm{CBCT}$ 영상에서 측정 시에 는 더 크게 측정될 것으로 예상된다.

이전 연구들에서 상악 중절치 접촉점을 지나는 정중선과 상 악 중절치 접촉점과 하악 중절치 접촉점을 지나는 선들이 기준 선으로 사용되었다. 이는 편리하지만 전치부 치열 관계에 의해 영향을 받는다는 단점이 있어 본 연구에서는 Waford 등히이 제 안한 bicondylar line을 기준선으로 하여 견치의 경사도를 평가 하였다. Warford 등 ${ }^{13)}$ 은 $63.20 \pm 10.66^{\circ}$ 라고 보고하였고 본 연구에서는 $64.6 \pm 28.5^{\circ}$ 로 조사되었으나, 이 계측치는 치료 및 합병증과의 유의적인 상관관계가 없는 것으로 조사되었다. Warford 등로도 angulation 보다 견치가 위치한 sector가 맹
출 예측에 더 중요하다고 하였다.

상악 견치의 매복의 국소적 원인으로는 치배의 변위, 치낭과 치주인대의 결함, 유치의 조기 상실 또는 만기 잔존, 맹출 공간 의 부족, 과잉치, 낭종, 치아종, 외상과 이에 따른 유착 등을 주 요 원인으로 들 수 있으나 이러한 국소적 원인으로 설명할 수 없는 매복의 경우도 많다. 이러한 견치 매복의 발생을 설명하는 많은 이론들이 있으나 크게 Guidance theory와 Genetic theory로 나눌 수 있다. 견치의 맹출을 유도하는 요인들의 이상에 의해 매복된다는 guidance theory를 지지하는 증거로는 상악 측절치의 크기 이상이나 결손과 관련하여 상악 견치가 매복된 다는 연구들이 있다 ${ }^{10}$. 유전적인 원인에 의해 견치가 매복된다 는 genetic theory와 관련하여, Baccetti ${ }^{18)}$ 는 다른 치과적 이상 과 견치 매복 사이의 연관성에 대해 언급했고, Peck 등 ${ }^{12)}$ 은 매 복 견치 환자 중 $33 \%$ 가 다른 부위의 선천적 결손치를 갖는다 고 보고하였다. 여성에서 남성에 비해 2 배 정도 빈번하게 관찰 된다는 점도 genetic theory를 지지하는 증거가 된다.

상악 측절치는 상악 견치의 맹출을 유도하는 역할을 한다고 보고되었다 ${ }^{19)}$. 인접한 상악 측절치의 결손이 있는 경우 상악 견 치가 구개측으로 2.4 배 더 매복된다는 보고도 있다 ${ }^{20)}$. 매복된 견치만을 연구 대상으로 한 본 연구에서는 측절치의 발육이상 을 보이는 경우가 전체의 $18.9 \%$ 로 관찰되어 국소적 원인 요소 가 관찰되는 경우 중에서 가장 많았다. 따라서 상악 측절치의 발육 이상이나 결손이 관찰되는 경우 상악 견치의 매복 가능성 에 대해 인지하고 그 맹출 양상을 주기적으로 평가하여 조기에 매복을 발견하고 처치하는 것이 필요하다.

매복견치에 대한 조기 발견과 치료의 중요성은 Becker 등1) 에 의한 연구에 의해 조사되었는데, 성인(평균 28.8세)에서 상 악 매복 견치를 교정적으로 견인할 경우 $69.5 \%$ 의 성공률을 보 였으나 어린 집단(평균 13.7 세)에서는 $100 \%$ 의 성공률을 보였 다고 하였다. 따라서 매복 견치의 조기 진단은 치료와 예후에 중요한 요소이다.

이른 시기부터 주기적인 검진을 통해 상악 견치가 매복되어 있거나 변위되어 맹출하는 경우 $10 \sim 13$ 세 즈음에 유견치를 발 거해 주는 것이 예방적인 혹은 조기치료 차원에서 가장 최선의 방법 중의 하나다 ${ }^{22}$. Ericson과 $\mathrm{Kurol}^{23)}$ 은 상악 견치가 측절치 치관 중심선보다 원심에 있는 경우 11 세 이전에 유견치를 발거 해 주면 $91 \%$ 가 정상적으로 맹출 한다고 하였다.

조기의 예방적 처치만으로 매복이 해결되지 않을 경우에도 상악 견치는 교합, 악궁의 형태, 안정성, 그리고 기능을 결정하 는 중요한 치아이므로 매복된 견치에 대한 치료 선택 중 첫 번 째는 치아의 외과적 노출과 교정적 견인에 의한 견치의 보존이 어야 한다. 그러나 교정적 견인을 결정하고 시행하기 위해서는 매복된 견치의 삼차원적 위치와 견치 치축의 경사도 등을 고려 해야 한다. 따라서 본 연구에서는 매복된 견치의 위치 관계와 여러 치료 방법 중 교정적 견인의 시행 여부에 대한 통계적 분 석을 시행하였다. 그 결과, 견치의 위치관계 중 협-구개, 근심원심 위치관계와 유의적인 관련성이 있었으며 $(p<0.05)$, 인접 치근 대비 수직적인 위치와는 관련성이 없었다 $(p>0.05)$. 치 
열궁에 비해 협측에 위치할수록, 교합평면으로부터의 거리와 교합평면과 이루는 각이 증가할수록 교정적 견인 이외의 치료 (해당 견치의 발거, 매복된 원인의 제거 등)가 시행되는 경향을 보였다.

또한 이번 연구에서 견치의 위치관계와 합병증의 상관관계에 대해서도 조사하였는데, 관찰된 합병증 중 인접 치근의 흡수와 인접 치아의 변위에 대해 분석하였다. 이외의 합병증은 표본 수 가 적어 통계적인 분석이 불가능하였다. Ericson과 $\mathrm{Kurol}^{24.25)}$ 은 매복된 상악 견치에 의해 인접한 측절치의 치근 흡수가 $12.5 \%$ 에서 관찰된다고 하였고 파노라마영상만 있는 경우보다 $\mathrm{CBCT}$ 에서 관찰할 경우 더 잘 관찰할 수 있다고 하였다. $\mathrm{CBCT}$ 영상을 이용한 Jung 등 15$)$ 은 $30.1 \%$ 에서 영구 절치 치근 의 흡수가 관찰된다고 보고하였다. 파노라마방사선영상과 $\mathrm{CBCT}$ 영상을 모두 이용한 본 연구에서는 중절치의 치근을 흡 수시키는 경우를 포함하여 $15.1 \%$ 에서 인접 치근의 흡수가 관 찰되었다.

매복된 견치가 치열궁보다 더 협측에 위치할 경우 인접 치아 를 변위시키는 경향이 5.771 odds ratio 만큼 증가하였으며 견 치 영역과 소구치 원심에 존재할 경우 인접 치아 변위에 대한 odds ratio가 각각 $0.242,0.033$ 으로 나타났다. 인접 치근의 흡수는 견치의 근원심적 위치와 관련이 있었으며 $(p<0.05)$, 견치 치근이 중절치 근심에 위치할 경우 치근 흡수가 견치 영역 에 위치할 경우와 비교할 때, odds ratio는 37.703으로 나타났 다. 매복된 견치 교두정이 측절치 치축 근심에 위치할 경우 인 접 치근의 흡수가 유의적으로 더 많이 발생한다고 보고한 Jung 등ㄷㅇㅇㅢ 연구와 유사한 결과를 보였다. 따라서 주기적인 검진 시 견치 치근이 중절치, 측절치 근심에 위치하는 것으로 생각되는 경우 견치의 매복에 대한 조기 진단과 적절한 치료 개입이 필요 할 것으로 생각된다.

이전에 매복된 상악 견치에 대해 행해진 연구들은 주로 치아 또는 골격 기준점에 대한 매복 견치의 3 차원적 위치 관계에 대 해서만 조사한 연구들이 대부분이다. 본 연구에서는 성장 중인 아이들에서 발견되는 매복된 견치를 파노라마방사선영상과 $\mathrm{CBCT}$ 영상에서 3차원적 위치 관계를 분석하고 추가적으로 매 복된 위치 및 경사도와 관련하여 치료 방법의 선택과 합병증의 발생의 상관관계를 분석하였으며, 이를 통해 매복된 견치의 치 료 선택에 있어 필요한 정보를 얻을 수 있다고 생각된다.

\section{V. 결 론}

상악 견치의 매복은 여러 가지 부작용을 유발하고 이후의 교 정치료를 복잡하게 만드는 요인이 되므로 조기진단과 정확한 치료계획의 수립이 필요하다. 본 연구 결과 상악 견치 교두정이 중절치 근심에 위치할 경우와 협측에 위치할 경우 인접 치아를 변위시키거나 흡수시키는 합병증이 발생할 경향이 증가하는 것 으로 관찰되어, 견치가 이러한 위치에 있거나 상악 측절치의 발 육이상이 관찰되는 경우 조기치료가 필요할 수 있다고 생각된 다. $\mathrm{CBCT}$ 와 파노라마방사선영상을 통한 매복된 상악 견치의
위치를 분석하는 것은 치료법을 결정하는데 있어 도움을 줄 수 있을 것이라고 생각되며, 본 연구는 매복된 상악 견치의 3 차원 적 위치정보와 치료 및 합병증과의 상관관계에 대한 정보를 제 공하여 매복된 상악 견치의 치료에 도움을 줄 것으로 생각된다.

\section{References}

1. Grover PS, Lorton L : The incidence of unerupted permanent teeth and related clinical cases. Oral Surg Oral Med Oral Pathol, 59:420-425, 1985.

2. Ericson S, Kurol J : Resorption of maxillary lateral incisors caused by ectopic eruption of the canines. Am J Orthod Dentofacial Orthop, 94:503-13, 1988.

3. Fox NA, Fletcher GA, Horner K : Localizing maxillary canines using panoramic tomography. Br Dent J, 179:416-20, 1995.

4. Stewart JA, Heo G, Major PW et al. : Factors that relate to treatment duration for patients with palatally impacted maxillary canines. Am $J$ Orthod Dentofacial Orthop, 119:216-25, 2001.

5. Bishara SE : Clinical management of impacted maxillary canines. Semin Orthod, 4:87, 1998.

6. Stellzig A, Basdra EK, Komposch G : The etiology of canine tooth impaction-A space analysis. Fortschr Kieferorthop, 55:97, 1994.

7. Caprioglio A, Siani L, Caprioglio C: Guided eruption of palatally impacted canines through combined use of 3-dimensional computerized tomography scans and the easy cuspid device. World J Orthod, 8:109, 2007.

8. Fournier A, Turcotte JY, Bernard C. : Orthodontic in the treatment of maxillary impacted canines. Am J Orthod, 81:236-9, 1982.

9. Jacoby $\mathrm{H}$ : The "ballista spring" system for impacted teeth. Am J Orthod Dentofacial Orthop, 75:143-51, 1979.

10. OliverRG, Mannion JE, Robinson JM : Morphology of the maxillary lateral incisor in cases of unilateral impaction of the maxillary canine. Br J Ortho, 16:916, 1989

11. Liu DG, Zhang WL, Ma XC et al. : Localization of impacted maxillary canines and observation of adjacent incisor resorption with cone-beam computed tomography. Oral Surg Oral Med Oral Pathol, 105:91-98, 2008.

12. Peck S, Peck L, Kataja M : The palatally displaced canine as a dental anomaly of genetic origin. Angle Orthod, 64:249-56, 1994. 
13. Waford JH Jr, Grandhi RK, Tira DE : Prediction of maxillary canine impaction using sectors and angular measurement. Am J Orthod Dentofacial Orthop, 124:651-655, 2003.

14. Carol M, Petrina P, Graham JR : The radiographic localization of impacted maxillary canines: a comparison of methods. Eur J Orthod, 23:25-31, 2001.

15. Jung YH, H Liang, Cho BH et al. : The assessment of impacted maxillary canine position with panoramic radiography and cone beam CT, Dentomaxillofac Radiol, 41:356-360, 2012

16. Anand KS and Nigel MK : Early prediction of maxillary canine impaction from panoramic radiographs, Am J Orthod Dentofacial Orthop, 142:45-51, 2012

17. Kim HJ, Park HS, Kwon OW : Evaluation of potency of panoramic radiography for estimating the position of maxillary impacted canines using 3D CT, Korean J Orthod, 38:265-274, 2008.

18. Baccetti $\mathrm{T}$ : A controlled study of associated dental anomalies. Angle Orthod, 68:267-72, 1988.

19. Broadbent BH : Ontogenic development of occlusion. Angle Orthod, 11:223-41, 1941.
20. Becker A, Smith P, Behar R : the incidence of anomalous lateral incisors in relation to palatally displaced cuspid. Angle Orthod, 51:24-29, 1984.

21. Becker A, Chaushu S. : Success rate and duration of orthodontic treatment for adult patients with palatally impacted maxillary canines. Am J Orthod Dentofacial Orthop, 124:509-14, 2003.

22. Jacobs $S G$ : Reducing the incidences of palatally impacted maxillary canines by extraction of deciduous canines: a useful preventive/interceptive orthodontic procedure. Case reports. Aust Dent J, 37:611, 1992.

23. Ericson S, Kurol J : Early treatment of palatally erupting maxillary canines by extraction of the primar canines. Eur J Orthod, 10:283-295, 1988.

24. Ericson S, Kurol J : Radiographic examination of ectopically erupting maxillary canines. Am J Orthod Dentofacial Orthop, 91:483-492, 1987.

25. Ericson S, Kurol J : Incisor resoption caused by maxillary cuspids. A radiographic study. Angle Orthod, 57:332-346, 1987. 
국문초록

\title{
Cone beam CT와 파노라마방사선사진을 이용한 매복 상악 견치의 3차원적 분석
}

\author{
전상윤 · 이난영 · 이상호
}

\section{조선대학교 치의학전문대학원 소아치과학교실}

견치의 맹출은 영구치열의 이행에 중요하다. 견치 매복의 원인으로 유치의 조기 상실 또는 만기 잔존, 신생물 등이 있으며 측절치 이상이 상악 견치 매복을 야기할 수 있다. 치료되지 않은 매복 견치는 부정교합, 낭종 등을 야기하고 교정치료를 복잡 하게 한다. 이 연구의 목적은 매복된 상악 견치의 위치를 조사하여 치료 및 합병증과의 관계를 규명하는 것이다. 상악 견치 매복으로 진단된 89명의 파노라마사진과 전산화단층영상을 사용하여 견치의 위치를 평가하였다. 시행된 치료와 합병증과의 상관관계에 대해 조사하였다. 가장 흔한 매복 위치는 치열궁 영역이었고 협측과 구개측 순이었다. 교정적 견인이 가장 빈번 히 선택되었으며 합병증으로는 인접치를 변위시키는 경우가 가장 흔했다. 협측에 매복 시 변위를 일으키는 경향이 높았고, 협측에 매복될수록 교정적 견인이 덜 시행되었다. 중절치 근심에 매복 시 치근 흡수를 일으키는 경향이 더 높았다. 그러므로 상악 견치에 대한 검진을 통해 조기 진단과 적절한 치료의 시행이 필요하다.

주요어: 상악 견치, 매복치, 전산화단층촬영 